\title{
Pengembangan Modul Pembelajaran Matematika dengan PENDEKatan KonTEKSTUAL
}

\author{
I Ketut Suastika $^{1)}$, Amaylya Rahmawati ${ }^{2)}$ \\ ${ }^{1,2)}$ Pendidikan Matematika Universitas Kanjuruhan Malang \\ ${ }^{1)}$ E-mail: suastika@unikama.ac.id \\ ${ }^{2)}$ E-mail: amaylyarahma@gmail.com
}

\begin{abstract}
Abstrak. Penelitian ini bertujuan untuk mengembangkan modul matematika dengan pendekatan kontekstual. Dalam penelitian pengembangan ini mengacu pada model pengembangan ADDIE. Pengembangan dilakukan melalui analisis, desain, pengembangan, implementasi, dan evaluasi. Fokus pada tulisan ini adalah memaparkan hasil implementasi dan evaluasinya untuk modul matematika yang telah dikembangkan. Evaluasi yang dilakukan pada implementasi ini adalah untuk melihat kepraktisan dan keefektifan modul. Kepraktisan modul dilihat dari hasil angket respon siswa dan hasil angket respon guru, sedangkan keefektifan modul dilihat dari hasil posttest siswa. Hasil angket respon siswa diperoleh persentase rata-rata sebesar 79\% dengan kriteria "baik", sedangkan hasil angket respon guru adalah 95\% dengan kriteria "sangat baik", dan hasil posttest siswa mendapat persentase $68 \%$ dengan kriteria "baik". Berdasarkan evaluasi yang dilakukan pada implementasi dapat dikatakan modul memenuhi kriteria "praktis" dan "efektif".
\end{abstract}

Kata kunci: pengembangan, modul matematika, pendekatan kontekstual

\section{Pendahuluan}

Matematika akan dirasa lebih bermakna apabila bahan ajar yang digunakan dalam pembelajaran memuat materi yang dikaitkan dengan konteks nyata dalam kehidupan sehari-hari. Bahan ajar akan lebih mudah mudah dipahami melalui materi yang berdasarkan pengalaman dan pengamatan dalam permasalahan kehidupan sehari-hari. Konsep matematika yang disajikan dalam bentuk konkret akan lebih mudah dipahami dengan baik. Oleh karena itu, pembelajaran matematika hendaknya dimulai dengan permasalahan yang sesuai dengan lingkungan atau situasi siswa. Pembelajaran yang menekankan siswa untuk memahami materi dengan mengaitkan materi pembelajaran ke dalam konteks kehidupan nyata dikatakan pembelajaran dengan pendekatan kontekstual (Komalasari, 2010).

Wahyuningtyas \& Ketut (2016) menyatakan bahwa pembelajaran kontekstual adalah sistem pembelajaran yang cocok dengan otak untuk menghasilkan makna dengan menghubungkan konten akademik dengan konteks kehidupan sehari-hari siswa. Melalui model pembelajaran kontekstual, pengajaran tidak hanya mentransformasi pengetahuan dari seorang guru ke siswa dengan menhafal sejumlah konsep yang sepertinya terlepas dari kehidupan nyata, tetapi lebih menekankan pada memfalisitasi siswa mencari kemampuan untuk hidup (kecakapan hidup) pada apa yang mereka pelajari. Nurhadi (2009) juga menekankan bahwa, melalui pendekatan kontekstual, siswa diharapkan belajar melalui 'mengalami', dan bukan 'menghafal'. Pendekatan kontekstual dapat menciptakan pembelajaran yang menyenangkan dan diinginkan oleh siswa. Di kelas kontekstual, guru tugasnya adalah membantu siswa mencapai tujuan mereka. Sementara itu, Suastika\&Wahyuningtyas (2018) mengatakan belum tersedianya buku matematika yang mendukung pembelajaran dengan pendekatan kontekstual.

Shofan, dkk. (2013) mengatakan, karakter maupun kemampuan siswa dalam belajar berbeda-beda, sehingga tidak semua siswa dapat dilayani kebutuhannyasecara individu.. Salah satu setrategi yang dapat diterapkan dalam pembelajaran untuk mewadahi kebutuhan siswa secara mandiri adalah pembelajaran individual menggunakan modul. Parmin \& Peniati (2012) mengatakan, modul adalah salah satu komponen penting dalam pembelajaran karena dapat membantu siswa memperoleh informasi penting tentang materi pembelajaran. Winkel (2009) mengatakan, modul pembelajaran merupakan satuan program belajar terkecil, yang dipelajari oleh siswa secara mandiri. Rufii (2015) menyatakan, one of media that can make students able to work independently to analyze rotational motion is the module. Modul yang berkualitas perlu memperhatikan 


\section{- - - Jurnal Pendidikan Matematika Indonesia \\ Volum 4 Nomor 2 bulan September 2019 Page 58 - 61 \\ p-ISSN: 2477-5967 e-ISSN: 2477-8443}

karakteristik yang diperlukan pada modul (Suastika \& Wahyuningtyas, 2018; Suryawati et al., 2010), antara lain: (a) Self instruction; (b) Self contained; (c) Berdiri sendiri (stand alone); (d) Adaptif; (e) Bersahabat / akrab (user friendly); (f) Konsistensi dalam penggunaan font, spasi, layout; (g) Memiliki organisasi penulisan yang jelas.

Dengan adanya modul matematika yang dibuat dengan bahasa yang mudah dipahami, menarik, dan juga kontekstual maka siswa akan lebih mudah untuk memahami konsep yang terkandung dalam materi yang mereka pelajari. Modul matematika dengan pendekatan kontekstual diharapkan akan bermanfaat mempermudah siswa dalam belajar matematika dan juga mempermudah guru dalam melaksanakan pembelajaran matematika. Oleh karena itu perlu dikembangkan modul matematika dengan pendekatan kontekstual yang dapat membantu siswa untuk belajar secara mandiri.

\section{Metode PEnelitian}

Prosedur pengembangan mengacu model pengembangan ADDIE. Tahapan dalam model pengembangan ADDIE adalah sebagai berikut:

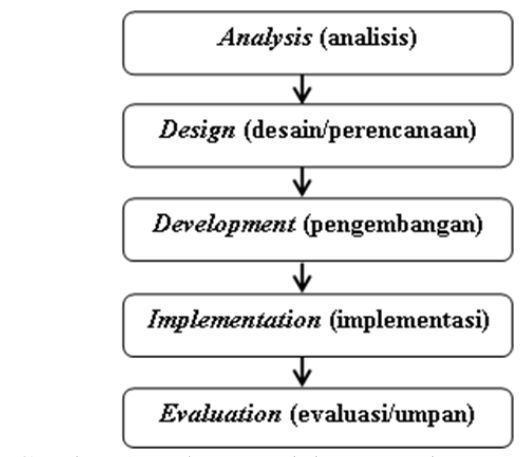

Gambar 1. Tahap Model Pengembangan ADDIE

Prosedur pengembangan dari tahap model ADDIE pada pengembangan ini sebagai berikut:

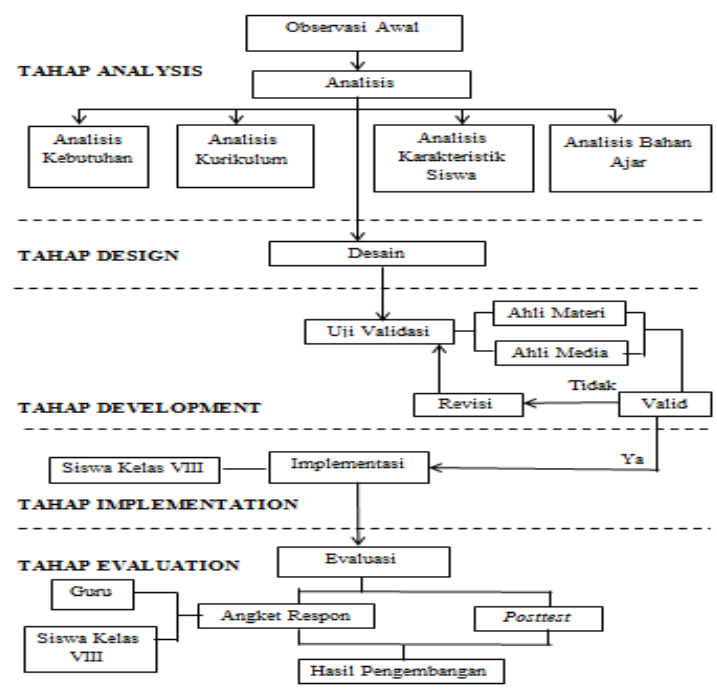

Gambar 2. Prosedur Pengembangan Modul
Teknik analisis data yang dilakukan menggunakan teknik analisis data persentase. Rumus yang digunakan dalam teknik analisis sebagai berikut:

$$
P=\frac{\sum X}{N} \times 100 \%
$$

$$
\begin{array}{ll}
\text { Keterangan: } \\
P & : \text { Persentase skor } \\
\sum X & : \text { Jumlah Skor } \\
N & : \text { Skor maksimal }
\end{array}
$$

Kepraktisan modul dilihat dari hasil angket respon siswa dan juga angket respon dari guru. Angket respon siswa ini bertujuan untuk mengukur kepraktisan modul dilihat dari aspek isi, penyajian, kemenarikan, dan kebermanfaatan. Angket respon guru bertujuan untuk menilai kepraktisan modul dalam pembelajaran. Aspek yang dinilai pada angket respon guru yaitu: isi atau materi, tampilan, dan keterlaksanaan pembelajaran dengan menggunakan modul.

Kriteria penilaian untuk menentukan respon siswa maupun respon guru terhadap modul dengan pendekatan kontekstual digunakan kriteria berdasarkan Sunarti dan Rahmawati (2012) yang disajikan pada Tabel I. Pada penelitian ini, modul dikatakan praktis jika hasil angket respon guru maupun hasil angket respon siswa memenuhi kreteria minimal "baik".

TABEL I

Kriteria Analisis Persentase Angket

\begin{tabular}{cc}
\hline $\begin{array}{c}\text { Interval Persentase hasil } \\
\text { angket } \mathbf{( 1 0 0 \% )}\end{array}$ & Kriteria \\
\hline $85-100$ & Baik Sekali \\
$75-84$ & Baik \\
$60-74$ & Cukup \\
$40-59$ & Kurang \\
$0-39$ & Gagal \\
\hline
\end{tabular}

Instrumen yang digunakan untuk mengukur keefektifan modul adalah tes hasil belajar siswa (Posttest). Tes ini diberikan setelah siswa selesai pembelajaran dengan menggunakan modul. Seorang siswa dinyatakan telah tuntas apabila nilai ketuntasan belajarnya lebih besar dari Kreteria Ketuntasan Minimal (KKM) yang telah ditetapkan oleh sekolah. KKM pada mata pelajaran matematika di sekolah tempat peneliti melakukan penelitian adalah 81 . Modul yang dikembangkan dikatakan efektif apabila persentase tes hasil belajar siswa memenuhi kriteria minimal "baik" dengan berdasarkan Tabel II.

TABEL III

Kriteria Penilaian Kecakapan Akademik

\begin{tabular}{cc}
\hline Ketuntasan & Kriteria \\
\hline$X>80 \%$ & Sangat Baik \\
$60 \%<X \leq 80 \%$ & Baik \\
$40 \%<X \leq 60 \%$ & Cukup \\
$20 \%<X \leq 40 \%$ & Kurang \\
$X \leq 20 \%$ & Sangat Kurang \\
\hline
\end{tabular}




\section{- - - Jurnal Pendidikan Matematika Indonesia \\ Volum 4 Nomor 2 bulan September 2019 Page 58 - 61 \\ p-ISSN: 2477-5967 e-ISSN: 2477-8443}

$$
X=\frac{L}{n} \times 100 \%
$$

\section{Keterangan:}

$L:$ jumlah siswa yang tuntas

$n$ : jumlah seluruh siswa

\section{HASIL DAN PEMBAHASAN}

Modul ini dikembangkan dengan model ADDIE yang terdiri dari 5 tahap, yaitu Analysis, Design, Development, Implementation, dan Evaluation. Penelitian dan pengembangan ini menghasilkan sebuah produk berupa modul matematika dengan pendekatan kontekstual pada materi sistem persamaan linear dua variabel. Modul yang dikembangkan terdiri dari kata pengantar, petunjuk modul, daftar isi, kompetensi, kegiatan pembelajaran, uji kompetensi, daftar pustaka, dan kunci jawaban. Pada kegiatan pembelajaran terdiri dari dua unit, masing-masing unit mengacu prinsip pendekatan kontekstual. Ada tujuh komponen prinsip pendekatan kontekstual yaitu kontruktivisme, menemukan, bertanya, masyarakat belajar, pemodelan, refelksi, dan penilaian sebenarnya.

Pada tahap implementation ini, ujicoba dilakukan pada siswa kelas VIII di SMP Negeri 12 Malang. Pada implementasi ini digunakan modul dengan pendekatan kontekstual. Pada implementasi ini dilakukan evaluasi untuk melihat kepraktisan dan keefektifan modul. Kepraktisan modul dilihat dari hasil angket respon siswa dan hasil angket respon guru. Untuk keefektifan modul dilihat dari hasil posttest siswa.

\section{a. Hasil angket respon siswa}

Siswa diberikan lembar penilaian yang berkaitan dengan penggunaan modul untuk mengetahui tanggapan siswa mengenai modul dalam pembelajaran. Hasil angket respon siswa disajikan pada Tabel III

TABEL IIIII

Hasil Angket Respon Siswa

\begin{tabular}{ccc}
\hline Aspek & Persentase & Kriteria \\
\hline Kemenarikan & $83 \%$ & Baik \\
Kebermanfaatan & $76 \%$ & Baik \\
Penyajian & $76 \%$ & Baik \\
Isi & $80 \%$ & Baik \\
Rata-rata & $79 \%$ & Baik \\
\hline
\end{tabular}

Penelitian pada aspek kebermanfaatan dengan pernyataan bahwa siswa merasa modul yang dibuat dapat mengarahkan siswa untuk membangun pengetahuannya sehingga benarbenar memahami materi. Penelitian ini sesuai dengan hasil penelitian Suastika (2018) yang menyatakan pembelajaran dengan modul dapat berpengaruh terhadap capaian pembelajaran. penelitian ini sejalan dengan penelitian Andari (2012), bahwa dengan menggunakan pendekatan kontekstual membuat siswa lebih mudah memahami dan mengingat apa yang dipelajari. Selanjutnya aspek penyajian yang dikaitkan kehidupan sehari-hari dapat menyesuaikan kemampuan siswa. Hal ini sesuai dengan penelitian Danuri (2014) bahwa modul matematika dengan pendekatan kontekstual dapat memfasilitasi pemahaman konsep dan kemandirian siswa. Pada aspek isi modul diberikan persoalan yang mudah dipahami dalam pembelajaran matematika. Hal ini sesuai dengan pendapat Hamdunah, dkk (2017) dengan adanya modul siswa dapat memahami konsep pelajaran dengan baik sesuai dengan gaya belajarnya sendiri.

\section{b. Hasil angket respon oleh guru}

Angket respon yang dinilai oleh guru dilakukan setelah pembelajaran dengan menggunakan modul. Hasil angket respon guru disajikan pada Tabel IV.

TABEL IVV

Hasil Angket Respon oleh Guru

\begin{tabular}{ccc}
\hline Aspek & Persentase & Kriteria \\
\hline Isi & $88 \%$ & Baik Sekali \\
Tampilan & $100 \%$ & Baik Sekali \\
$\begin{array}{c}\text { Keterlaksanaan dalam } \\
\text { pembelajaran } \\
\text { Rata-rata }\end{array}$ & $96 \%$ & Baik Sekali \\
\hline
\end{tabular}

Total rata-rata persentase dari ketiga aspek tersebut adalah 95\% dengan kriteria "baik sekali". Hasil angket dari guru pada aspek keterlaksanaan dalam pembelajaran memperoleh persentase $96 \%$ dengan kriteria "baik sekali". Ini mengindikasikan bahwa guru tidak ada kesulitan dalam melaksanakan pembelajaran menggunakan modul matematika yang dikembangkan. Namun demikian, guru memberikan saran terhadap modul yang dikembangkan sebagai acuan perbaikan yaitu dengan menyederhanakan contoh soal latihan agar mudah dipahami oleh siswa.

Adapun hasil posttest diketahui sebanyak 17 siswa yang tuntas dan 8 siswa lainnya yang belum tuntas. Sehingga persentase keefektifan modul adalah $68 \%$ dengan kriteria "baik". Ini mengindikasikan modul efektif untuk digunakan dalam pembelajaran. Hasil ini mendukung hasil penelitian Wahyuningtyas dan Suastika (2016) bahwa, penerapan modul dapat mengkondisikan kegiatan pembelajaran lebih terencana dengan baik, mandiri, tuntas dan dengan hasil (output) yang jelas. Hasil ini mendukung juga hasil penelitian Sulianto (2011), belajar dengan modul dapat mengasah kemampuan siswa dalam memecahkan masalah dalam pembelajaran matematika. Hasil penelitian ini mendukung juga hasil penelitian Lasmiyati (2014), bahwa pembelajaran matematika yang menggunakan modul lebih baik dibandingkan kelas yang tidak menggunakan modul.

\section{KESIMPULAN}

Berdasarkan hasil penelitian maka didapat kesimpulan sebagai berikut.

1. Pengembangan modul matematika dengan pendekatan kontekstual dikembangan menggunakan model ADDIE 
yang terdiri dari 5 tahap, yaitu Analysis, Design, Development, Implementation, dan Evaluation. Penelitian dan pengembangan ini menghasilkan sebuah produk berupa modul matematika dengan pendekatan kontekstual pada materi sistem persamaan linear dua variabel. Modul yang dikembangkan terdiri dari kata pengantar, petunjuk modul, daftar isi, kompetensi, kegiatan pembelajaran, uji kompetensi, daftar pustaka, dan kunci jawaban. Pada kegiatan pembelajaran terdiri dari dua unit, masing-masing unit mengacu prinsip pendekatan kontekstual. Ada tujuh komponen prinsip pendekatan kontekstual yaitu kontruktivisme, menemukan, bertanya, masyarakat belajar, pemodelan, refelksi, dan penilaian sebenarnya.

Tahap Implementation meliputi uji coba lapangan yang dilaksanakan di kelas VIII SMP Negeri 12 Malang. Pada tahap ini dilakukan penilaian untuk melihat kepraktisan dan keefektifan modul. Kepraktisan modul dilihat dari angket respon guru dan angket respon siswa, sedangkan keefektifan modul dilihat dari hasil posttest siswa.

2. Berdasarkan hasil penilaian kepraktisan modul diperoleh respon siswa dengan rata-rata persentase $79 \%$ dengan kriteria "baik" dan respon guru diperoleh rata-rata persentase 95\% dengan kriteria "baik sekali". Ketuntasan belajar siswa melalui posttest untuk mengukur keefektifan modul diperoleh rata-rata persentase sebesar $68 \%$ dengan kriteria "baik".

\section{REFERENSI}

Andari, T. (2012). Efektifitas Pembelajaran Matematika Menggunakan Pendekatan Kontekstual terhadap Prestasi Belajar Matematika Ditinjau dari Kemampuan Awal Siswa Kelas V SD SeKecamatan Bangunrejo Kabupaten Lampung Tengah. Jurnal Ilmiah Pendidikan Matematika. $1(1)$.

Danuri. (2014). Pengembangan Modul Matematika dengan Pendekatan Kontekstual untuk Memfasilitasi Kemandirian Belajar Siswa SD/MI. Jurnal Pendidikan Dasar Islam, 6(1), 25-36

Hamdunah, Suryani, M., \& Wijaya, F. I. (2017). Pengembangan Modul Berbasis Realistik pada Materi Lingkaran untuk Siswa Kelas VIII SMP. Jurnal Pelangi, 9(2). 135-143

Komalasari, K. (2010). Pembelajaran Kontekstual: Konsep dan Aplikasi. Bandung: PT Refika Aditama.

Lasmiyati dan Harta, I. (2014). Pengembangan Modul Pembelajaran untuk Meningkatkan Pemahaman Konsep dan Minat SMP. Jurnal Pyhtagoras, 9 (2), 161-174.
Nurhadi \& Senduk, Agus G. (2009). Pembelajaran Kontekstual. Surabaya: PT JePe Press Media Utama

Parmin \& Peniati. E. 2012. Development of Course Module Learning Strategy of Teaching Science Based on Science Result of Science. Indonesian Science. Education Journal, 1(1), 2339-1286.

Rufii. 2015. Developing Module on Constructivist Learning Strategies to Promote Students' Independent and Performance. Internasional Journal of Education, 7(1), 1948-5476.

Shofan, M., Sa'dijah, C., dan Slamet. (2013). Pengembangan Modul Pembelajaran Bilangan Bulat dengan Pendekatan Kontekstual untuk Siswa Kelas IV SD/MI. (online). Terdapat di http://jurnalonline.um.ac.id/artikelF98AOF2A4C247D519F011 A66CF2F1F22.pdf

Suastika, I K. (2018). Pengembangan Modul Pembelajaran Bilangan Berbasis Tematik Saintifik. Jurnal Inspirasi Pendidikan, 8 (1). 24-32

Suastika, I. K. dan Wahyuningtyas, D.T. (2018). Developing Module of Fractional using Contextual Teaching and Learning Approach. Jurnal Pancaran Pendidikan, 7 (1). 23-32

Sulianto, J. (2009). Keefektifan Model Pembelajaran Kontekstual dengn Pendekatan Open Ended dalam Aspek Penalaran dan Pemecahan masalah pada materi segitiga di kelas VII. Jurnal Pyhtagoras, 5(2), 73-86

Sunarti dan Rahmawati, S. (2012). Penilaian Hasil Belajar. Yogyakarta: Andi Offset.

Suryawati, K., Osman, and Meerah, T.S.M. (2010). The Effectiveness of RANGKA Contextual Teaching and Learning on Student's Problem Solving Skills and Scientific Attitude. Procedia-Soc. Behav.Sci. Vol 9, pp. 1717-1721

Wahyuningtyas, D.T. dan Suastika, I K. . (2016). Developing Learning Modules of Numbers for Primary School Students Using Contextual Teaching and Learning Approach. Jurnal Pendidikan Dasar Indonesia, 1(2). 33-36

Winkel. (2009). Psikologi Pengajaran. Yogyakarta : Media Abadi. 